\title{
EFEK PEMACUAN APOPTOSIS FRAKSI ETIL ASETAT EKSTRAK ETANOL AKAR PASAK BUMI (Eurycoma longifolia Jack) TERHADAP SEL HeLa
}

\author{
Isnaniati Romadhoni Indarwati, Nurkhasanah
}

Fakultas Farmasi Universitas Ahmad Dahlan

\begin{abstract}
Pasak bumi is one of the Indonesian original plants having anticancer activity. Eurycomanone was isolated from Eurycoma longofolia, Jack root was proven to have cytotoxic effect and induce apoptosis on Hela cells. The objective this study was to know the cytotoxic activity of ethyl acetate fraction of ethanolic extract of the Eurycoma longifolia, Jack root on Hela cells and the mode of death. Ethyl acetate fraction was obtained from the ethyl acetate soluble fraction from residue of chloroform fraction of ethanolic extract of Eurycoma longifolia Jack roots. The cytotoxic assay was performed using MTT test method with concentration series used in this study were $1000 ; 750 ; 500 ; 400 ; 200 ; 100 ; 50 ; 12,5 ; 6,25 ; 3,125 ;$ and 1,5625 $\mu \mathrm{g} / \mathrm{ml}$. Absorbance was measured at wavelength of $550 \mathrm{~nm}$ using ELISA reader. Apoptosis assay were observed using Giemsa staining. MTT assay indicated that etil asetat fraction of ethanolic extract of the Eurycoma longofolia, Jack root showed cytotoxic activity againts Hela cells with $\mathrm{IC}_{50}$ value $3,70 \mu \mathrm{g} / \mathrm{ml}$. The result of apoptosis assay indicated that the ethyl acetate fraction of ethanolic extract of the Eurycoma longofolia, Jack root induce apoptosis. The apoptotic cells was observed wrinkle, rounded and dark colors leading to chromatin condensation.
\end{abstract}

Keywords: pasak bumi, cytotoxic, apoptosis, Hela cells

\begin{abstract}
ABSTRAK
Pasak bumi (Eurycoma longofolia, Jack ) adalah salah satu tanaman asli Indonesia yang memiliki potensi antikanker. Salah satu kandungan kimia yang terdapat pada akar pasak bumi yaitu eurikomanon terbukti bersifat sitotoksik dan dapat menginduksi apoptosis pada sel Hela. Penelitian ini bertujuan untuk mengetahui aktivitas sitotoksik fraksi etil asetat ekstrak etanol akar pasak bumi terhadap sel Hela dan mengetahui mekanisme kematian yang ditimbulkannya. Fraksi etil asetat diperoleh dari fraksi larut etil asetat dari residu fraksi kloroform ekstrak etanol akar pasak bumi. Uji sitotoksik dilakukan dengan metode MTT mengunakan seri kadar 1000; 750; 500; 400; 200; 100; 50; 25; 12,5; 6,25; 3,125; dan 1,5625 $\mu \mathrm{g} / \mathrm{ml}$. Absorbansi diukur dengan ELISA reader pada panjang gelombang $550 \mathrm{~nm}$. Uji pemacuan apoptosis dilakukan dengan menggunakan metode pewarnaan Giemsa. Hasil uji MTT menunjukkan bahwa fraksi etil asetat ekstrak etanol akar pasak bumi (Eurycoma longofolia, Jack) memiliki aktivitas sitotoksik terhadap sel Hela dengan nilai $\mathrm{IC}_{50}$ sebesar 3,70 $\mu \mathrm{g} / \mathrm{ml}$. Fraksi etil asetat ekstrak etanol akar pasak bumi terbukti memacu apoptosis ditandai dengan morfologi sel yang mengkerut, tampak bulat, dan menyerap warna lebih pekat karena terjadinya kondensasi kromatin.
\end{abstract}

Kata kunci: pasak bumi, uji sitotoksik, apoptosis, sel Hela 


\section{PENDAHULUAN}

Populasi sel dan keseimbangan jaringan dipengaruhi oleh proliferasi, diferensiasi, dan apoptosis (Lumongga, 2008). Sel mengalami kerusakan yang besar akan mengaktifkan apoptosis yakni program kematian sel dengan tujuan untuk mengeliminasi sel yang rusak atau yang tidak diinginkan dan jumlah sel yang terlalu banyak, sehingga jumlah sel dalam jaringan dapat dikendalikan. Apoptosis juga menghilangkan sel yang mungkin berbahaya bagi tubuh (Nurhayati dan Lusiyanti, 2006). Proses apoptosis ditandai dengan sel mengkerut, kondensasi kromatin, fragmentasi dan terbentuknya badan-badan apoptotik (Utami, 2007).

Kanker adalah segolongan penyakit yang ditandai dengan pembelahan sel yang tidak terkendali dan kemampuan sel-sel tersebut untuk menyerang jaringan biologis lainnya, baik dengan pertumbuhan langsung di jaringan yang bersebelahan (invasi) atau dengan migrasi sel (metastasis) ke tempat yang lebih jauh. Jenis-jenis kanker yang dikenal banyak sekali dan hampir semua organ dapat dihinggapi penyakit ini, termasuk limfa, darah, sumsum, dan otak (Tjay dan Rahardja, 2002). Sel kanker dapat juga menyerang mulut atau leher rahim, yang disebut kanker serviks atau kanker leher rahim. Kanker leher rahim adalah kanker yang menyerang bagian ujung bawah rahim yang menonjol ke liang senggama (vagina). Kanker serviks atau kanker leher rahim merupakan jenis kanker yang kedua terbanyak pada perempuan di seluruh dunia setelah kanker payudara. Namun, di Indonesia kanker serviks menduduki peringkat pertama (Dalimartha, 1999).

Salah satu tanaman yang potensial dikembangkan untuk pengobatan kanker adalah pasak bumi (Eurycoma longifolia Jack.). Bagian yang dapat digunakan untuk pengobatan penyakit adalah akar, batang, dan daunnya. Khasiat pasak bumi yang paling dikenal adalah afrodisiaka. Khasiat sebagai antikanker telah dibuktikan dengan penelitian-penelitian yang telah dilakukan. Kuo, et. al., (2003) membuktikan bahwa alkaloid â-karbolin yang diisolasi dari akar pasak bumi memiliki aktivitas sitotoksik. Senyawa golongan quasinoid dan alkaloid yang terdapat pada akar pasak bumi bertanggungjawab terhadap aktivitas sitotoksik pada sel kanker payudara, usus besar, fibrocarsoma, paru-paru dan melanoma (Kardono, et al., 1991).

Jiwajinda, et. al., (2002) melakukan penelitian terhadap pasak bumi yang menunjukkan bahwa kuasinoid yang terkandung dalam pasak bumi mampu menghambat pertumbuhan tumor yaitu 14,15â-dihidroksiklaineanon ( $\left.\mathrm{IC}_{50}=5 \grave{M}\right)$, longilakton memberikan efek antisistosomal yang signifikan pada konsentrasi 200 ìg/ml, serta 11-dehidroksiklaineanon dan 15â-O14-hidroksiklaneanon menunjukkan aktivitas antiplasmodial yang poten pada $\mathrm{IC}_{50}=2 \mathrm{ig} / \mathrm{ml}$. Penelitian Mustofa dan Qomariah (2004) berhasil membuktikan bahwa ekstrak metanol akar pasak bumi bersifat sitotoksik terhadap sel Hela dengan $\mathrm{IC}_{50}=2,13 \mathrm{ìg} / \mathrm{ml}$. Nurkhasanah dan Azimahtol (2006) membuktikan bahwa senyawa eurikomanon yang terkandung dalam akar pasak bumi mampu menginduksi apoptosis pada sel Hela. Pencarian bahan obat antikanker dari alam umumnya difokuskan untuk mencari senyawa aktif yang memiliki kemampuan menekan proliferasi sel kanker, mempunyai efek sitotoksik, antimimotik atau memiliki kemampuan dalam menginduksi terjadinya proses apoptosis pada sel kanker. Penelitian 
ini adalah bagian dari upaya penelusuran fraksi aktif dari ekstrak etanol akar pasak bumi. Ekstrak etanol dipilih karena diharapkan dapat menyari senyawa-senyawa yang polar maupun nonpolar dan dalam fraksi etil asetat diharapkan tersari senyawasenyawa aktif yang bersifat antikanker.

\section{METODE PENELITIAN}

\section{Alat}

Alat-alat yang digunakan antara lain seperangkat alat-alat gelas, microplate 96 sumuran, ELISA reader (Slt), mikroskop inversi (Olimpus), sentrifuse (Sigma), coverslips, gelas objek, chamber, dan plate silika gel F 254.

\section{Bahan}

Bahan yang digunakan yaitu serbuk akar Pasak Bumi, etanol $96 \%$ (pelarut ekstraksi), kloroform dan etil asetat (fraksinasi). Bahan untuk uji sitotoksisitas dan apoptosis adalah sel Hela, medium pertumbuhan RPMI, MTT (3- $(4,5$ dimetiltiazol-2-il)difeniltetrazolium bromide), pewarna Giemsa.

\section{Jalannya Penelitian \\ a. Pembuatan Ekstrak Etanol dan Fraksi Etil Asetat Akar Pasak Bumi}

Ekstrak etanol akar pasak bumi dibuat dengan menggunakan metode maserasi dengan pelarut etanol $96 \%$ selama 3 hari. Maserat dievaporasi dan selanjutnya diuapkan diatas waterbath sampai kental dan ditimbang. Ekstrak selanjutnya difraksinasi menggunakan kloroform diperoleh sari kloroform dan residu. Residu yang diperoleh ditambahkan etil asetat, bagian yang larut dalam etil asetat diambil sebagai fraksi etil asetat, kemudian diuapkan dan ditimbang.

\section{b. Pembuatan Sediaan Uji}

Ekstrak ditimbang sebanyak $20 \mathrm{mg}$ kemudian dilarutkan dalam DMSO sebanyak 100 ìl. Larutan stok tersebut diambil setengahnya, ditambahkan DMSO sebanyak 50 ìl dan ditambahkan RPMI sampai 2500 il, kemudian dibuat seri kadar $1000 ; 750 ; 500 ; 400 ; 200 ; 100 ; 50 ; 12,5$; 6,$25 ; 3,125$ dan $1,5625 \mathrm{ig} / \mathrm{ml}$, dibuat dengan cara pengenceran bertingkat.

\section{c. Uji Aktivitas Sitotoksik Metode MTT}

Suspensi sel HeLa (kepadatan $2 \times 10^{4} \mathrm{sel} /$ sumuran) didistribusikan ke dalam plate 96 sumuran dan ditambahkan larutan senyawa uji pada tiap sumuran. Plate yang berisi suspensi sel dan larutan senyawa uji diinkubasi pada suhu $37^{\circ} \mathrm{C}$ selama 72 jam. Masing-masing sumuran ditambahkan 10 $\mu \mathrm{L}$ MTT $5 \mathrm{mg} / \mathrm{mL}$ pada akhir inkubasi dan diinkubasi kembali selama 4 jam pada tempat gelap pada suhu kamar. Serapan dibaca dengan ELISA Reader pada panjang gelombang $550 \mathrm{~nm}$.

\section{d. Uji Apoptosis}

Sel HeLa ditanam pada coverslips yang dimasukkan dalam microplate 6 sumuran sehingga diperoleh kepadatan $2 \mathrm{x}$ $10^{4} \mathrm{sel} /$ sumuran. Selanjutnya ditambahkan larutan uji dengan kadar sesuai $\mathrm{IC}_{50}$ dan diinkubasi selama 24 jam. Setelah diinkubasi medium diambil, dicuci dengan PBS dan PBS dibuang, dan difiksasi dengan metanol selama 30 detik. Selanjutnya metanol dibuang, ditambahkan larutan giemsa $1 \mathrm{ml}$ dan didiamkan selama 10 menit, kemudian dicuci dengan aquadest hingga jernih dan diamati di bawah mikroskop.

\section{e. Uji Kromatografi Lapis Tipis}

Kloroform dan metanol (4: 1) dimasukkan dalam chamber dan dijenuhkan, sampel fraksi etil asetat dilarutkan dalam pelarut etanol $96 \%$ sebanyak $1 \mathrm{ml}$. Setelah jenuh plate silika GF 254 ukuran 10 X 10 
cm disiapkan. Standard eurikomanon, ekstrak etanol, dan sampel (fraksi kloroform, fraksi etil asetat, dan fraksi metanol- air) ditotolkan dengan pipa kapiler ukuran $1 \mu 1$. Plate silika dimasukkan kedalam chamber yang telah dijenuhkan dan dielusi sampai batas elusi. Deteksi dilakukan di bawah sinar UV $366 \mathrm{~nm}$.

\section{HASIL DAN PEMBAHASAN}

\section{Uji Sitotoksisitas terhadap Sel HeLa}

Uji sitotoksisitas fraksi etil asetat ekstrak etanol akar pasak bumi (Eurycoma longifolia, Jack) ini dilakukan untuk mengetahui potensi ketoksikannya terhadap sel Hela. Parameter yang digunakan dalam uji sitotoksisitas ini adalah $\mathrm{IC}_{50}$, merupakan konsentrasi ekstrak yang mampu menghambat proliferasi sel sebesar $50 \%$ populasi. Sel yang digunakan dalam penelitian ini adalah sel Hela yang merupakan turunan sel kanker leher rahim (serviks) manusia.

Uji sitotoksisitas fraksi etil asetat ekstrak etanol akar pasak bumi terhadap sel Hela dilakukan dengan metode MTT., karena metode tersebut terbukti lebih sensitif, cepat dan akurat dibandingkan dengan metode perhitungan langsung (Doyle and Griffits, 2000). Penetapan dengan metode ini merupakan pengukuran secara kolorimetri yang didasarkan terjadinya pembentukan garam formazan yang merupakan zat warna ungu dan tidak larut air. Reagen MTT akan dipecah menjadi garam formazan oleh enzim reduktase suksinat tetrazolinum yang termasuk dalam rantai respirasi mitokondria dan hanya aktif pada sel hidup. Reagen stopper (SDS $10 \%$ dalam $\mathrm{HCl} 0,01 \mathrm{~N}$ ) bertujuan untuk menghentikan reaksi enzimatis dan melarutkan kristal formazan. Intensitas warna ungu ditetapkan secara spektrofotometri dengan ELISA reader pada panjang gelombang $550 \mathrm{~nm}$.

Uji sitotoksisitas terhadap sel Hela dilakukan dengan media biakan RPMI 1640. Pada penelitian ini media RPMI 1640 digunakan sebagai media pertumbuhan sel dan DMSO digunakan sebagai pelarut dari sediaan uji. Penggunaan dimetil sulfoksida (DMSO) memiliki keuntungan yaitu bersifat tidak toksik terhadap sel pada kadar rendah, dapat melarutkan senyawa polar atau nonpolar, dapat bercampur dengan air, merupakan pelarut yang baik untuk ion anorganik maupun organik, dan tidak berwarna (Fessenden and Fessenden, 1994). Hasil pengamatan uji sitotoksik fraksi etil

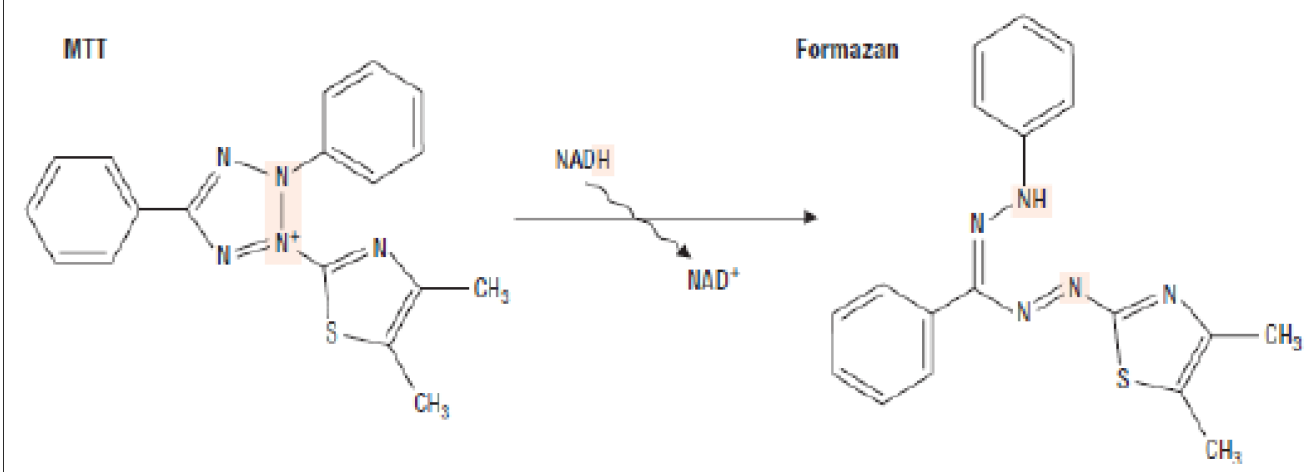

Gambar 1. Reaksi reduksi MTT menjadi formazan (Wyllie, 2000) 
Tabel 1. Hasil perhitungan \% kematian oleh perlakuan fraksi etil asetat ekstrak etanol akar pasak bumi terhadap sel Hela

\begin{tabular}{cccc}
\hline & \multicolumn{2}{c}{ Fraksi etil asetat ekstrak etanol } & \\
Kadar & Log Kadar & \% Kematian & Probit \\
\hline 1000 & 3,000 & 99,94 & \\
750 & 2,874 & 102,62 & \\
500 & 2,699 & 101,20 & \\
400 & 2,602 & 101,16 & \\
200 & 2,301 & 100,84 & 7,29 \\
100 & 2,000 & 98,84 & 6,21 \\
50 & 1,699 & 88,59 & 5,60 \\
12,5 & 1,097 & 72,77 & 5,17 \\
6,25 & 0,796 & 57,58 & 5,15 \\
3,125 & 0,495 & 56,95 & 4,49 \\
1,5625 & 0,194 & 30,67 & \\
\hline
\end{tabular}

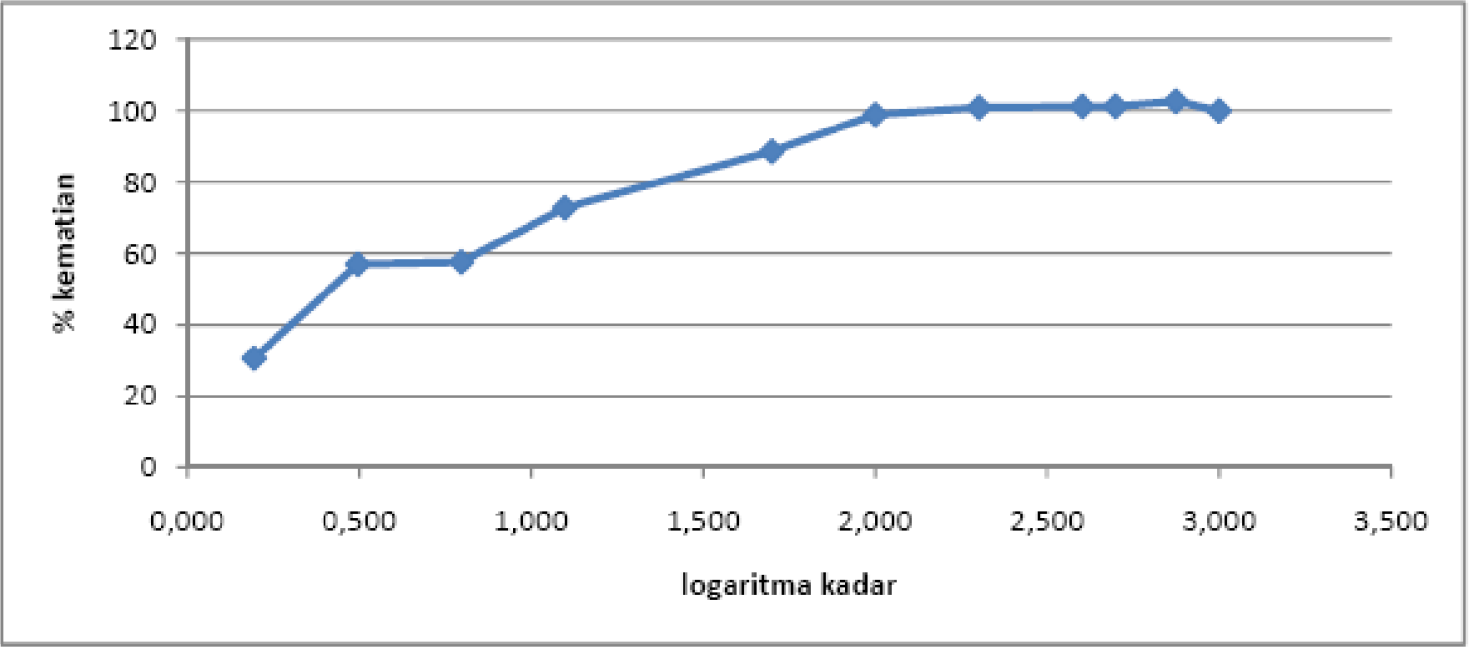

asetat ekstrak etanol akar pasak bumi terhadap sel Hela dengan metode MTT berupa data absorbansi jumlah sel hidup, dari data tersebut dihitung persentase kematian sel kemudian dikonversi menjadi harga probit sehingga diperoleh data yang tertera pada Tabel 1.

Data pada Tabel I dapat dibuat grafik hubungan log kadar senyawa uji terhadap persen kematian sel yang ditunjukkan oleh Gambar 2 dan grafik hubungan log kadar versus angka probit yang ditunjukkan pada Gambar 3.

Dari grafik hubungan log kadar fraksi etil asetat ekstrak etanol akar pasak bumi versus angka probit hasil konversi dari \% kematian diperoleh persamaan regresi linier $\mathrm{Y}=1,362 \times+4,226$ dengan koefisien korelasi 0,966 dan diperoleh harga $\mathrm{IC}_{50}$ sebesar 3,70 ìg/ml. Nilai ini menunjukkan bahwa fraksi etil asetat poten terhadap sel Hela karena nilai IC $_{50}$ kurang dari 20 ìg/ $\mathrm{ml}$. Penelitian ini menunjukkan bahwa fraksi 


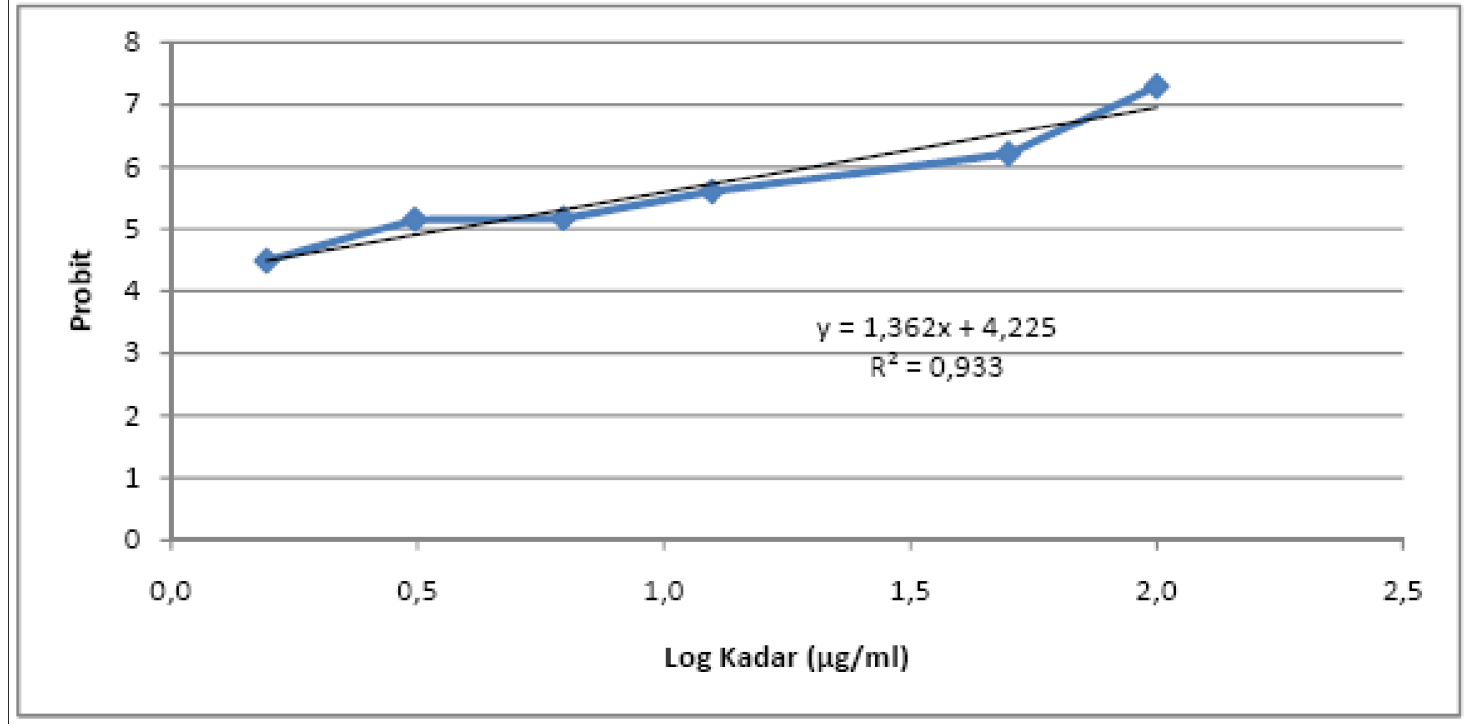

Gambar 3. Grafik hubungan antara logaritma kadar $(\mu \mathrm{g} / \mathrm{ml})$ fraksi etil asetat ekstrak etanol akar pasak bumi versus angka probit terhadap sel Hela

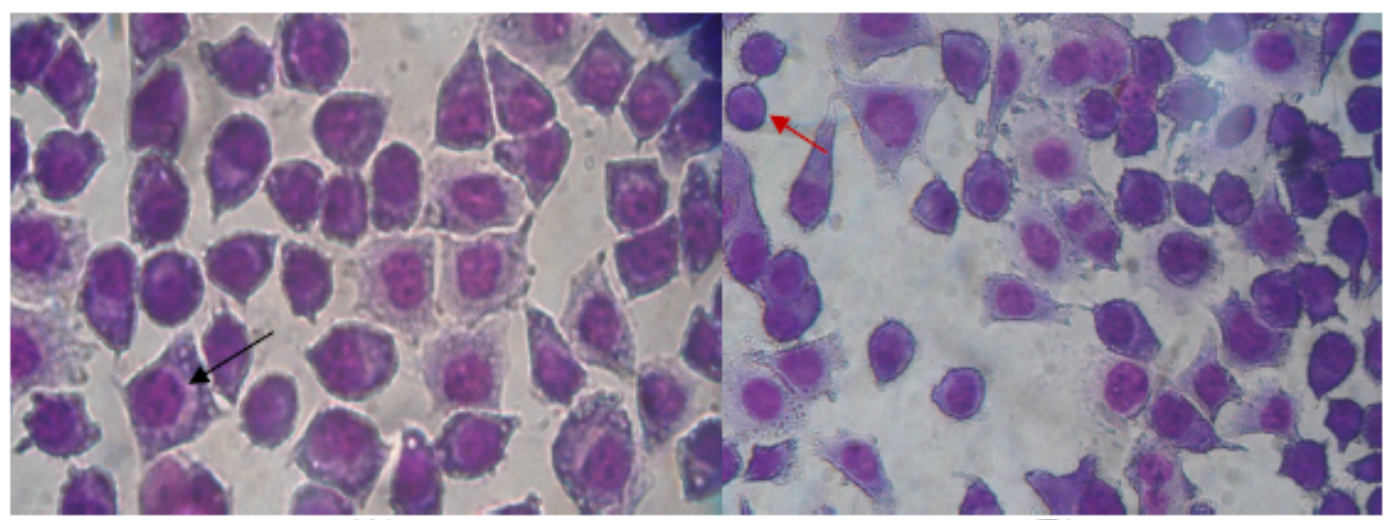

(A)

(B)

Gambar 4. Hasil pengecatan Giemsa (A) perlakuan kontrol, (B) perlakuan sampel fraksi etil asetat ekstrak etanol 3,125 $\mu \mathrm{g} / \mathrm{ml}$, anak panah hitam menunjukkan sel hidup dan anak panah merah menuniukkan sel mati

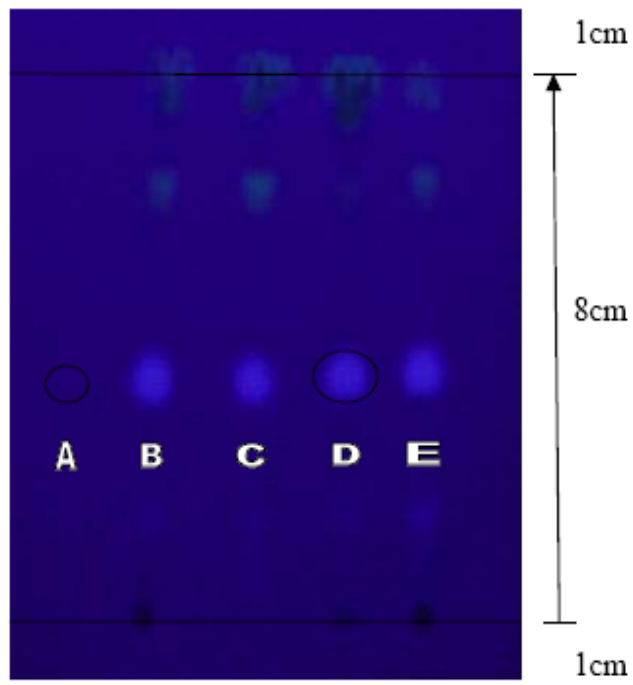

Gambar 5. Hasil KLT dengan fase diam silika gel F 254 dan fase gerak kloroform: metanol (4:1), (A) standard Eurikomanon, (B) ekstrak etanol, (C) fraksi kloroform ekstrak etanol, (D) fraksi etil asetat ekstrak etanol, dan (E) fraksi metanol air ekstrak etanol akar pasak bumi 
etil asetat merupakan fraksi aktif dari ekstrak etanol akar pasak bumi karena nilai $\mathrm{IC}_{50}$ lebih sedikit dibandingkan fraksi kloroform dan fraksi metanol-air. Nilai $\mathrm{IC}_{50}$ ekstrak etanol sebesar 14,5 $\mu \mathrm{g} / \mathrm{ml}$ (Budiyani, 2011), fraksi kloroform $\mathrm{IC}_{50}=7,24 \mu \mathrm{g} / \mathrm{ml}$ (Nevilia, 2011) dan fraksi metanol-air IC $_{50}$ sebesar 50,44 $\mu \mathrm{g} / \mathrm{ml}$ (Sa'diyah, 2011).

\section{Uji Apoptosis}

Metode yang digunakan dalam uji pemacuan apoptosis adalah pewarnaan Giemsa. Kelebihan dari pewarna Giemsa adalah mudah dijalankan dengan penyediaan yang sederhana dan biaya relatif lebih murah dibandingkan dengan pewarna lain. Namun demikian, pewarnaan Giemsa masih terdapat kendala dan keterbatasan karena hasilnya sebagian besar bergantung pada kemampuan penguji (Desrinawati, 2002). Pengaruh pemberian fraksi etil asetat ekstrak etanol akar pasak bumi (Eurycoma longifolia Jack) dengan menggunakan pewarna Giemsa ditunjukkan pada Gambar 4.

Gambar 5 menunjukkan bahwa (B) ekstrak etanol, (C) fraksi kloroform ekstrak etanol, (D) fraksi etil asetat ekstrak etanol, dan (E) fraksi metanol-air ekstrak etanol akar pasak bumi mengandung eurikomanon karena memiliki bercak yang sejajar dengan bercak standar eurikomanon (A) dan memiliki harga Rf yang sama yaitu 0,46.

\section{KESIMPULAN}

Fraksi etil asetat ekstrak etanol akar pasak bumi (Eurycoma longifolia, Jack.) mempunyai aktivitas sitotoksik terhadap sel HeLa dengan harga $\mathrm{IC}_{50}$ sebesar 3, $70 \mu \mathrm{g} /$ $\mathrm{ml}$ dan memacu apoptosis ditandai dengan morfologi sel yang mengkerut, tampak bulat, dan menyerap warna lebih pekat..

\section{DAFTAR PUSTAKA}

Budiyani, 2011, Efek Pemacuan Apoptosis

Ekstrak Etanol Akar Pasak Bumi

(Eurycoma longifolia, Jack.) terhadap Sel Hela, Skripsi, Universitas Ahmad Dahlan, Yogyakarta.

Desrinawati, 2002, Perbandingan Hasil Pemeriksaan Metoda Immunochromatographic Test (ICT) dengan Pewarnaan Giemsa pada Infeksi Malaria Falciparum, Universitas Sumatera Utara, Medan, 10.

Djajanegara, I., dan Wahyudi, P., 2009, Pemakaian Sel Hela dalam Uji Sitotoksisitas Fraksi Kloroform dan Etanol Ekstrak Daun Annona squamosa, Jurnal Ilmu Kefarmasian Indonesia, 7-11.

Doyle, A., and Griffiths, J.B., 2000, Cell and Tissue Culture for Medical Research, John Wiley \& Sons, Ltd, New York, 307-309, 311-312.

Dwipoyono, Bambang, 2007, Aktifitas Caspase 3 sebagai Indikator Apoptosis pada Sel Kanker Ovarium, Indonesian Journal of Cancer, 64.

Fessenden, J., \& Fessenden, R., 1994, Kimia Organik Jilid 2 Edisi Ketiga, diterjemahkan oleh Aloysius Hadyana Pudjaatmaka Ph.D., Erlangga, Surabaya.

Guo, Z., Vangapandu, S., Sindelar, R.W., Walker, L.A., Sindelar, R.D., 2005, Biologgicaly Active Quassinoids and Their Chemistry: Potential Leads for Drug Design, Current Medicinal Chemistry, 12, 173-190.

Jiwajinda, S., Viai, S., Akira, M., Masanori, K., Hiroma, K., Monique, G., Riad, E., Guy, B., Hajime, O., 2002, 
Invitro Anti-tumor Promoting and Anti-parasitic Activities of The Quassinoid from Eurycoma longifolia, a Medicinal Plant in Southeast Asia, Journal of Ethnopharmacology, 82, 55-58.

Kardono, L.B., Angerhofer, C.K., Tsauri, S., Padmawinata, K., Pezzuta, J.M., Kinghorn, A.D., 1991, Cytotoxic and antimalarial constituents of the roots of Eurycoma longifolia, J Nat Prod, 54, 1360-1367.

Kuo, P.C., Shie, L.S., Damu, A.G., Su, C.R., Huang C.H., Ke, C.H., Wu, J.B., Lin, A.J., Bastow, K.F., Lee, K.H., Wu, T.S., 2003, Cytotoxic and Antimalarial â-Carboline Alkaloids from the Roots of Eurycoma longifolia, J Nat Prod, 66, 13241327.

Lumongga, Fitriani, 2008, Apoptosis, Departemen Patologi Anatomi Fakultas Kedokteran Universitas Sumatera Utara, Medan.

Mustofa dan Qomariah, N., 2004, Aktivitas Antiplasmodial in vitro dan Sitotoksik Akar Pasak Bumi terhadap Malaria di Kalimantan Selatan, Medika, 3, 147-152.

Nevilia, A. S., 2011, Efek Pemacuan Apoptosis Fraksi Kloroform Ekstrak Etanol Akar Pasak Bumi (Eurycoma longifolia, Jack.) terhadap Sel Hela, Skripsi, Universitas Ahmad Dahlan, Yogyakarta.

Nurhayati, S. dan Lusiyanti, Y., 2006, Apoptosis dan Respon Biologik Sel sebagai Faktor Prognosa Radioterapi Kanker, Buletin Alara, 7, 57-66.
Nukhasanah Mahfudh and Azimahtol Hawariah L.P., 2008, Eurycomanone Induces Apoptosis Through the Up-Regualation of p53 in Human Cervical Carcinoma Cells, Journal of Cancer Molecules, 4, 109-115.

Nurkhasanah, Azimahtol Hawariah, L.P., and Latip, J., 2009, Morphological studies of apoptotic HeLa cells death induced by eurycomanone, Majalah Farmasi Indonesia, 20(4), 190 - 197.

Sa'diyah, M.A., 2011, Efek Pemacuan Apoptosis Fraksi Metanol-air Ekstrak Etanol Akar Pasak Bumi (Eurycoma longifolia, Jack.) terhadap Sel Hela, Skripsi, Universitas Ahmad Dahlan, Yogyakarta.

Sudjadi, 1988, Metode Pemisahan, Kanisius, Yogyakarta.

Tjay, T.H. dan Rahardja, K., 2002, Obatobat Penting, Edisi kelima, 197198, Elex Media Komputindo, Jakarta.

Utami, Sri, 2007, Peran Kaspase pada Apoptosis sebagai Salah Satu Usaha dalam Kemoterapi Kanker, JKM, 7, 95-102.

Wyllie, A., Donahue, V., Fischer, B., Hill, D., Keesey, J., and Manzow, S., 2000, Cell Death Apoptosis and Necrosis, The New England of Journal Medicine, Review Article 